\title{
New Insights Into the Pathogenesis of Alzheimer's Disease
}

\author{
Liyuan Fan ${ }^{1,2 \dagger}$, Chengyuan Mao ${ }^{1 \dagger}$, Xinchao Hu ${ }^{1}$, Shuo Zhang ${ }^{1,2}$, Zhihua Yang ${ }^{1,2}$, \\ Zhengwei Hu ${ }^{1,2}$, Huifang Sun ${ }^{1,2}$, Yu Fan ${ }^{1,2}$, Yali Dong ${ }^{1}$, Jing Yang ${ }^{1}$, Changhe Shi ${ }^{1 *}$ and \\ Yuming $X u^{1 *}$ \\ ${ }^{1}$ Department of Neurology, The First Affiliated Hospital of Zhengzhou University, Zhengzhou University, Zhengzhou, China, \\ ${ }^{2}$ Academy of Medical Sciences, Zhengzhou University, Zhengzhou, China
}

\section{OPEN ACCESS}

Edited by:

Jennifer S. Yokoyama

University of San Francisco,

United States

Reviewed by:

Claudia Kimie Suemoto,

University of São Paulo, Brazil

Antonio Giuliano Zippo,

Institute of Bioimaging and Molecular

Physiology (CNR), Italy

${ }^{*}$ Correspondence:

Changhe Shi

shichanghe@gmail.com

Yuming Xu

xuyuming@zzu.edu.cn

tThese authors have contributed equally to this work

Specialty section:

This article was submitted to

Dementia,

a section of the journal

Frontiers in Neurology

Received: 03 October 2019 Accepted: 27 November 2019 Published: 10 January 2020

Citation:

Fan L, Mao C, Hu X, Zhang S, Yang Z, Hu Z, Sun H, Fan Y, Dong Y, Yang J, Shi $C$ and $X u Y$ (2020) New Insights Into the Pathogenesis of Alzheimer's

Disease. Front. Neurol. 10:1312

doi: 10.3389/fneur.2019.01312
Alzheimer's disease (AD), a common neurodegenerative disease in the elderly and the most prevalent cause of dementia, is characterized by progressive cognitive impairment. The prevalence of $A D$ continues to increase worldwide, becoming a great healthcare challenge of the twenty-first century. In the more than 110 years since $A D$ was discovered, many related pathogenic mechanisms have been proposed, and the most recognized hypotheses are the amyloid and tau hypotheses. However, almost all clinical trials targeting these mechanisms have not identified any effective methods to treat $A D$. Scientists are gradually moving away from the simple assumption, as proposed in the original amyloid hypothesis, to new theories of pathogenesis, including gamma oscillations, prion transmission, cerebral vasoconstriction, growth hormone secretagogue receptor $1 \alpha(\mathrm{GHSR} 1 \alpha)$-mediated mechanism, and infection. To place these findings in context, we first reviewed the neuropathology of $A D$ and further discussed new insights in the pathogenesis of AD.

Keywords: Alzheimer's disease, amyloid, tauopathies, gamma rhythm, prions, ghrelin, pericytes, infection

\section{INTRODUCTION}

Alzheimer's disease (AD), which was first described by German Bavarian psychiatrist and neurologist Alois Alzheimer in 1907 (1), is the most common degenerative central nervous system disease in the elderly. According to the Alzheimer's Association, AD accounts for an estimated 60$80 \%$ of dementia cases (2). At present, there are 50 million AD patients worldwide, and its incidence doubles every 5 years after the age of 65 years (3). The main clinical manifestations are cognitive dysfunction, memory loss, and abnormal changes in personality. The pathological cause of AD is considered to be the senile plaque (SP) formed by amyloid beta $(\mathrm{A} \beta)$ and neurofibrillary tangles (NFTs) composed of phosphorylated tau protein, in the hippocampus.

$\mathrm{AD}$ can be late onset (LOAD) and sporadic (SAD) or early-onset (EOAD) and familial (FAD) (4). FAD is mainly associated with mutations in the $A \beta$ precursor protein $(A P P)$ and presenilin genes PSEN1 and PSEN2, whereas SAD has a complex etiology, involving genetic, environmental, metabolic, viral, and other factors (5). Apolipoprotein E (APOE) is a polymorphic protein with three isoforms, APOE2, APOE3, and APOE4, where APOE4 is the strongest genetic risk factor for SAD $(6,7)$. According to statistics, $40-50 \%$ of EOAD and $80 \%$ of LOAD are associated with $A P O E$. The strong affinity of $\mathrm{APOE}$ for $\mathrm{A} \beta$ affects the production, hydrolysis, and elimination of $\mathrm{A} \beta$ (8-10). Endogenous expression of APOE4 in stem-cell-derived neurons promotes the release of phosphorylated tau and predisposes neurons to injury and calcium dysregulation. Interestingly, 
$A P O E 2$ is a protective factor that reduces the incidence of $\mathrm{AD}$ and $A \beta$ accumulation and delays the age of onset (11-13). Some researchers have found that APOE4 expression in mouse models increases oligomer expression and plaque deposition, whereas this is reversed in expression of APOE2 (14). However, there is clear in vivo evidence that both APOE2 and APOE4 isoforms are involved in the process of $A \beta$ aggregation and deposition and associated with neurodegeneration, although the effect of APOE4 appears to be much stronger than that of APOE2 (15). Regardless, small-molecule inhibitors of APOE/A $\beta$ interaction may provide a therapeutic option for SAD, which accounts for more than $95 \%$ of $\mathrm{AD}$.

There are many hypotheses to explain $\mathrm{AD}$ pathogenesis, involving the amyloid cascade (16), tau hyperphosphorylation (17), neurotransmitters, and oxidative stress (18). However, the underlying causes and optimal treatment plans are still elusive. At present, there are a few drugs available that improve symptoms, mostly targeting $A \beta$ and tau, but these cannot delay progression of the disease. Researchers are beginning to explore new theories of the pathogenesis of $\mathrm{AD}$ from different perspectives, such as gamma oscillations, prion transmission, cerebral vasoconstriction, growth hormone secretagogue receptor $1 \alpha$ $($ GHSR $1 \alpha)$-mediated mechanism, and infection. Discoveries in these areas make it possible to reasonably explain the pathological mechanisms of $\mathrm{AD}$ and suggest potential effective treatments for AD. Herein, we review the two most recognized hypotheses and focus attention on novel developments in the pathophysiology of $\mathrm{AD}$.

\section{PATHOGENESIS HYPOTHESES}

Most of the recently proposed pathogenic mechanisms are derived from two fundamental hypotheses: the amyloid cascade hypothesis and the tau hyperphosphorylation hypothesis. First, we will review these two accepted hypotheses and the clinical research targeting them.

\section{Amyloid Cascade Hypothesis}

$\mathrm{A} \beta$ plaques were first proposed by Paul Blocq and George Mannesco when they discovered "circular accumulation in the brains of elderly patients" in 1892. After nearly a 100 years of research, Glenner isolated "beta-amyloid" from the meningeal vessels of Alzheimer cases and partially identified the peptide sequence (19). The amyloid hypothesis was first proposed by John Hardy and David Allsop in 1991 (20). A $\beta$ is a transmembrane protein which is produced by hydrolysis of the $A \beta$ precursor protein (APP) via the amyloidogenic pathway. Studies have shown that APP produces C-terminal fragments under the hydrolysis of $\alpha-, \beta-, \gamma-$, and $\eta$-secretases by three pathways (21) (Figure 1). The first non-amyloidogenic pathological pathway produces products which are neurotrophic and neuroprotective for nerve cells, such as the C-terminal fragment (CTF)- $\alpha$, the soluble ectodomain of APP- $\alpha(\operatorname{sAPP} \alpha)$, and other smaller fragments, through the involvement of $\alpha$ - and $\gamma$-secretases under normal circumstances. The second pathway is the amyloidogenic pathological pathway in which APP is cleaved to CTF- $\beta$ by $\beta$-secretase and then different lengths of $A \beta$ peptides by $\gamma$-secretase, including $A \beta 42$ which is more prone to aggregation and plaque formation than $A \beta 40$ and has stronger neurotoxicity $(22,23)$. The third pathway is the alternative processing route under physiological conditions by $\eta$-secretase.

$\mathrm{A} \beta$ in SPs is thought to be the initiating factor in the pathology of $\operatorname{AD}(24,25) . \mathrm{A} \beta$ deposited in the hippocampus and basal segment, in the form of neurotoxic amyloid plaques, recruits more $A \beta$ to form insoluble aggregates and induces mitochondrial damage (26), unstable homeostasis, and synaptic dysfunction (27). Microglia and astrocytes are activated and induce related inflammatory reactions and oxidation. Eventually, neuronal dysfunction and apoptosis occur, leading to AD. Tau protein kinase 1 can be activated by $A \beta$, leading to abnormal phosphorylation of tau protein and promoting the formation of paired helical filaments (PHFs) and NFT, which accelerate the development of tau pathology (28). Soluble $A \beta$ oligomers are suggested to be more toxic than $A \beta$ cellulose bodies (29). In 2011 , Ferreira officially proposed the "A $\beta$ oligomer pathogenic theory," suggesting that soluble $A \beta$ oligomers are the initiating factors leading to a series of pathological changes in $\mathrm{AD}$ (30). An increase of $A \beta$ oligomers in the cerebrospinal fluid (CSF) of AD patients has been reported in many studies (31). $\mathrm{A} \beta$ oligomers begin to accumulate in vivo 10 years or even decades before clinical symptoms and contribute to long-term potentiation (LTP) inhibition as well as enhanced long-term depression (LTD) (32), by acting on multiple receptors including $N$-methyl-D-aspartate (NMDA)-type glutamate and $\alpha 7$-nicotinic acetylcholine ( $\alpha 7-\mathrm{nACh})$ receptors (33), leading to synaptic dysfunction and impaired learning and memory (34). A $\beta 42$ oligomers also cause oxidative damage to synaptic membranes and induce hyperphosphorylation of tau protein $(35,36)$.

Currently, the goals of therapeutic strategies based on the $\mathrm{A} \beta$ hypothesis are to reduce $\mathrm{A} \beta$ formation and aggregation and increase $A \beta$ clearance $(16,24,37)$ (Table 1). The most direct action is to reduce $A \beta$ production by controlling BACE1 and $\gamma$-secretase activity (38-40). However, $\gamma$-secretase inhibitors lack substrate specificity for APP and are toxic to many organs (41). The drug avagacestat, which was the first to undergo clinical trials, has serious side effects such as tumors, gastrointestinal reactions, and rashes and did not achieve the desired effects; as such, related trials have ceased (42-44). The use of Encore's tarenflurbil, which has good security, has also been terminated because there is no obvious improvement in cognitive dysfunction (45). Other drugs have been disappointing to date, in some cases performing worse than placebos, with increased adverse reactions (e.g., semagacestat) (44). By contrast, BACE1 inhibitors have higher substrate specificity and are one of the main areas for anti-AD drug development. However, many Phase III trials have not shown significant clinical benefits and showed unanticipated adverse side effects (46), such as the inhibitor verubecestat, although it can reduce A $\beta$ in CSF by up to $90 \%(47,48)$. The termination of related clinical trials was announced early in 2018. In July 2019, a Phase II/III trial of the BACE1 inhibitor umibecestat was also terminated due to cognitive deterioration in participants.

In addition, animal experiments have demonstrated that it is feasible to enhance the clearance and degradation of $\mathrm{A} \beta$ (49) 


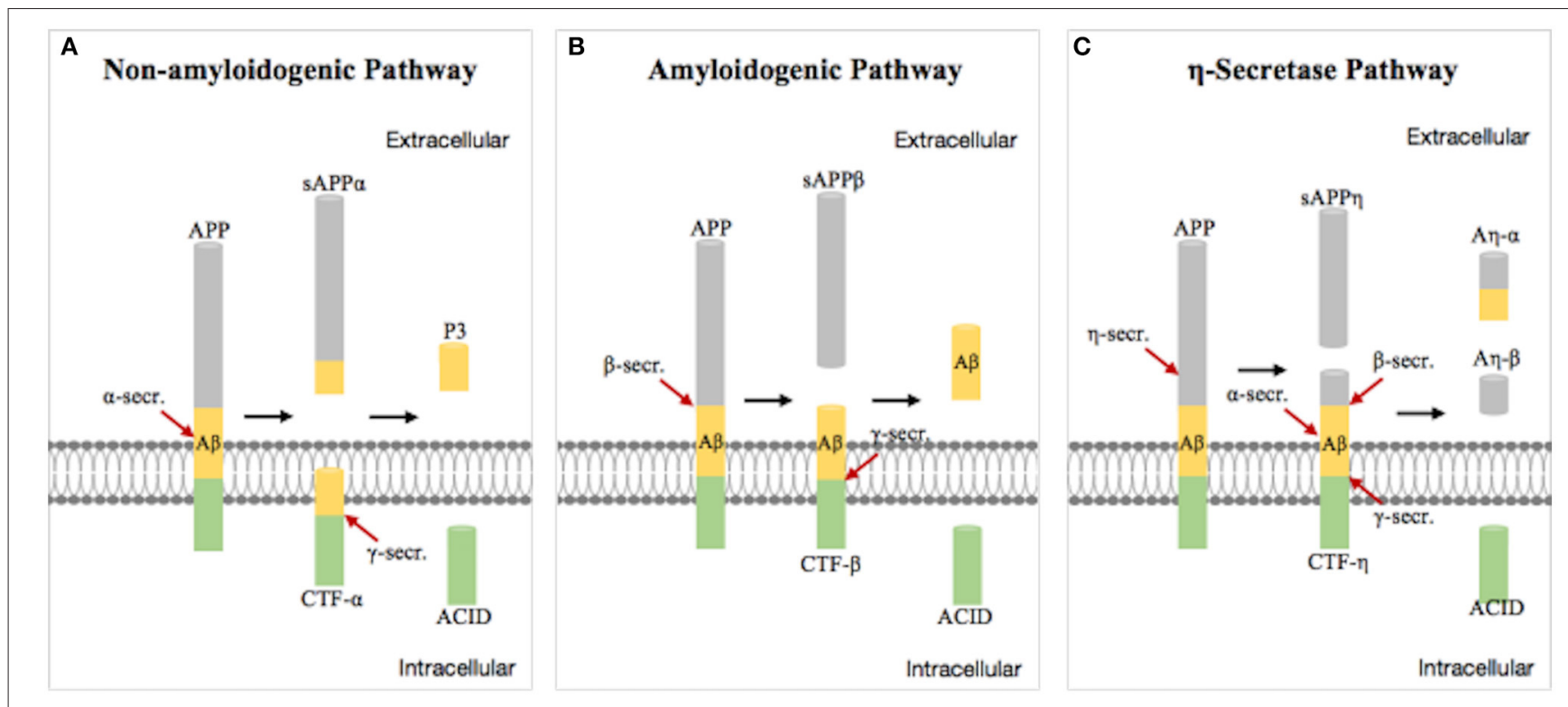

FIGURE 1 | Schematic diagram of the progressive cleavages of the amyloid beta (A $\beta$ ) precursor protein (APP) transmembrane domain. A $\beta$ peptide is generated from APP processing via the amyloidogenic pathway (B). (A,C) are non-amyloidogenic pathological pathway under physiological conditions.

TABLE 1 | Part of clinical studies on therapies in Alzheimer's disease (AD).

\begin{tabular}{llllll}
\hline Target & Drug & Clinicaltrials.gov & Study phase & Status & Main reasons for failure \\
\hline BACE1 & Verubecestat (MK-8931) & NCT01953601 & III & Terminated & Lack of efficacy \\
& Umibecestat (CNP520) & NCT03131453 & II/III & Terminated & Toxicity \\
$\gamma$-Secretase & Avagacestat & NCT00890890 & II & Terminated & Toxicity and lack of efficacy \\
& Semagacestat & NCT01035138 & III & Completed & Toxicity and lack of efficacy \\
& Tarenflurbil (MPC-7869) & NCT00380276 & III & Terminated & Lack of efficacy; increased adverse reactions; no \\
& Crenezumab & NCT02670083 & III & Terminated & Lack of efficacy \\
& Aducanumab (BIIB037) & NCT02484547 & III & Terminated & Lack of efficacy \\
& Azeliragon (TTP488) & NCT02080364 & III & Terminated & Lack of efficacy \\
tau & LMTM (TRx0237) & NCT01626378 & III & Completed & Toxicity and lack of efficacy \\
& Epothilone D & NCT01492374 & I & Completed & Toxicity
\end{tabular}

Data sources: www. clinicaltrials.gov.

BACE1, $\beta$-site amyloid precursor protein cleaving enzyme 1; A $\beta$, amyloid beta; $p$-tau, hyperphosphorylated tau peptide.

or promote the delivery of $A \beta$ to the periphery (50). Active immunity and passive immunity are research hot spots. This year, some Phase III trials, such as those for crenezumab and aducanumab, were terminated because they were ineffective and did not reach the primary endpoint, although they were able to reduce $A \beta$ deposition.

Researchers have also attempted to reduce $A \beta$ aggregation to improve brain pathology and cognition in mice (51), by using agents such as the endoglycosylation receptor inhibitor TTP488 (azeliragon) which showed good cognitive improvement in Phase II trials (52). However, the clinical Phase III trial was terminated because the desired effect was not achieved.

Recently, researchers at the University of Washington developed small synthetic alpha-peptides that target and inhibit small toxic oligomers and block $A \beta$ aggregation at an early stage. Good results were observed in AD mouse disease models and Caenorhabditis elegans (a nematode model of AD). However, whether this technique can be applied to humans is yet to be studied (53).

\section{Tau Hyperphosphorylation Hypothesis}

Tau is a microtubule-associated protein produced by alternative splicing of the MAPT gene (54). In 1988, Claude Wischik isolated tau from plaques in the brains of $\mathrm{AD}$ patients, demonstrating for the first time that tau protein may be the cause of dementia (55). Tau is mainly found in neuronal axons of the brain (56), combined with microtubules (MTs). The function of tau is to maintain microtubule structure and cytoplasmic transport 
function $(57,58)$, maintain synaptic structure and function (59), and regulate neuronal signaling. Tau is also a phosphoprotein whose phosphorylation and dephosphorylation may depend on the balance of protein kinase and protein phosphatase activity and is regulated by brain development. Under normal conditions, tau has few phosphorylation sites and negatively regulates the binding of tau to microtubules. Under pathological conditions, the phosphorylation of tau saturated.

The development of tau pathology is a complex multifactorial process. Hyperphosphorylated tau in $\mathrm{AD}$ patients' brains causes configuration changes and the loss of tubulin polymerization capacity $(60,61)$, resulting in defective microtubule functioning (62).

The elevated levels of cytosolic tau lead tau-tau interactions and polymerization to form insoluble PHFs and straight filaments (SFs) that result in the formation of intraneuronal fibrillar deposits known as NFTs (60). NFTs reduce the number of synapses, produce neurotoxicity (63), and cause cell dysfunction (64). Experiments have shown that hyperphosphorylation of tau is positively correlated with the degree of tau aggregation and the pathological severity of $\mathrm{AD}$ (65). Tau, rather than $\mathrm{A} \beta$, determines cognitive status (66). In addition, the acetylation and truncation of tau inhibit its ability to bind to microtubules and also promotes tau aggregation, mitochondrial dysfunction, and synaptic deficits (67-69). Interestingly, p-tau has been shown to spread between cells (70). Small soluble tau may be more harmful than NFT which can not only help the spread of pathological tau but can also affect neurodegeneration and cognition (71). In summary, due to its complexity, the pathogenesis of pathological tau remains to be elucidated.

In recent years, tau has gained much attention, in part because of the failure of various $A \beta$-targeting treatments in clinical trials and because tau pathology correlates better with cognitive impairments than do $A \beta$ lesions (Table 1). Inhibitors of kinases and tau aggregation, stabilizers of microtubules, and immunotherapeutic drugs have recently been investigated. Most of them show some toxicity and lack of efficacy, such as the inhibitor of tau aggregation, LMTM (TRx0237) (72). The antifungal molecule epothilone $\mathrm{D}$ proved to increase the number of microtubules, reduce the number of abnormal axons, and improve tau-related pathology in a mouse model of tau lesions $(73,74)$. However, the clinical trial of epothilone D was terminated because of adverse effects. AADvac1 as a tau vaccine showed good results in terms of safety and immune response in $\mathrm{AD}$ patients. However, further research is needed to demonstrate its clinical efficacy (75).

\section{NEW INSIGHTS INTO THE PATHOGENESIS OF AD}

With the prospect of an increasingly aging society, the number of $\mathrm{AD}$ patients and sociomedical burdens will increase dramatically. Currently, cholinesterase inhibitors (AChEIs) and the NMDA receptor antagonist are the only therapies for $\mathrm{AD}$ (76). However, these can only relieve symptoms and not delay the progress of $\mathrm{AD}$ (77-79). Moreover, three cholinesterase inhibitors, namely, donepezil, rivastigmine, and galantamine, which are approved by the US Food and Drug Administration, were proven to increase side effects, such as nausea, vomiting, and diarrhea. Although the NMDA receptor antagonist memantine showed good effects on improving cognitive function and behavioral disturbance scores (80), it causes severe hypotension, leading to fainting, and falls (81). According to statistics, AD drug development had a high failure rate of $99.6 \%$ in the decade between 2002 and 2012 (82). Based on these above unsatisfactory results, researchers are constantly proposing new pathogenic mechanisms.

\section{Gamma Oscillations Ameliorate Pathology and Cognitive Impairment in AD}

Gamma oscillations are rhythmic fluctuations of brain waves caused by activation of local circuits of excitatory and fast-spiking inhibitory neurons in the local field potential (LFP), resonating at $20-50 \mathrm{~Hz}$ and are associated with numerous higher-order cognitive functions, such as memory formation and attentional selection (83). Changes in gamma oscillations were reported in a variety of neurological diseases including AD. In TgCRND8 transgenic mice, the $\theta-\gamma$ crossover frequency coupling in the hippocampus was impaired before plaque formation in the brain (84). Furthermore, the reduction of slow gamma power in CA1 of 3xTg mice can result in impaired memory function (85). Moreover, hippocampal oscillations were also observed to affect spatial memory in a mouse model of tau pathology (86). These pieces of evidence suggest that the reactivation of gamma oscillations may play a role in protecting cognitive function in $\mathrm{AD}$.

Surprisingly, studies that replaced endogenous mouse APOE4 with the AD-linked human APOE4 gene showed that alleviated gamma impairments after replacement in mice rescued learning and memory deficits (87). Iaccarino and colleagues observed that behaviorally driven gamma oscillations in the $\mathrm{AD}$ mouse model are reduced before plaque formation or cognitive decline begins (88) (Figure 2). Using optogenetics in the hippocampus of 5XFAD mice and non-invasive light flicker to treat the visual cortex (VC) in multiple mouse models, they found that 40$\mathrm{Hz}$ gamma oscillation, but not other frequencies, reduced levels of $\mathrm{AD}$ pathology. Specifically, $\mathrm{A} \beta 1-40$ and $\mathrm{A} \beta 1-42$ isoforms in multiple $\mathrm{AD}$ mouse models (even in wild-type mice), tau phosphorylation staining in the tau P301S mouse model, and even plaque load in aged mice are reduced. Microglial responses were recruited, which is thought to be a protective function to reduce $A \beta$ by phagocytosis. The exact manner and consequences of microglial gamma oscillation changes remain to be determined. Nonetheless, these data suggest that reducing neuroinflammation may play an important role in improving neurodegeneration.

$\mathrm{AD}$ affects multiple brain regions critical to learning and memory, such as the hippocampus (HPC) and medial prefrontal cortex (mPFC). Therefore, researchers speculate that gamma oscillators, being generated locally and exhibiting similar frequencies in different brain regions, can become coupled by anatomical connections between the regions and may be more conducive to alleviating $\mathrm{AD}$ pathology and memory loss. 


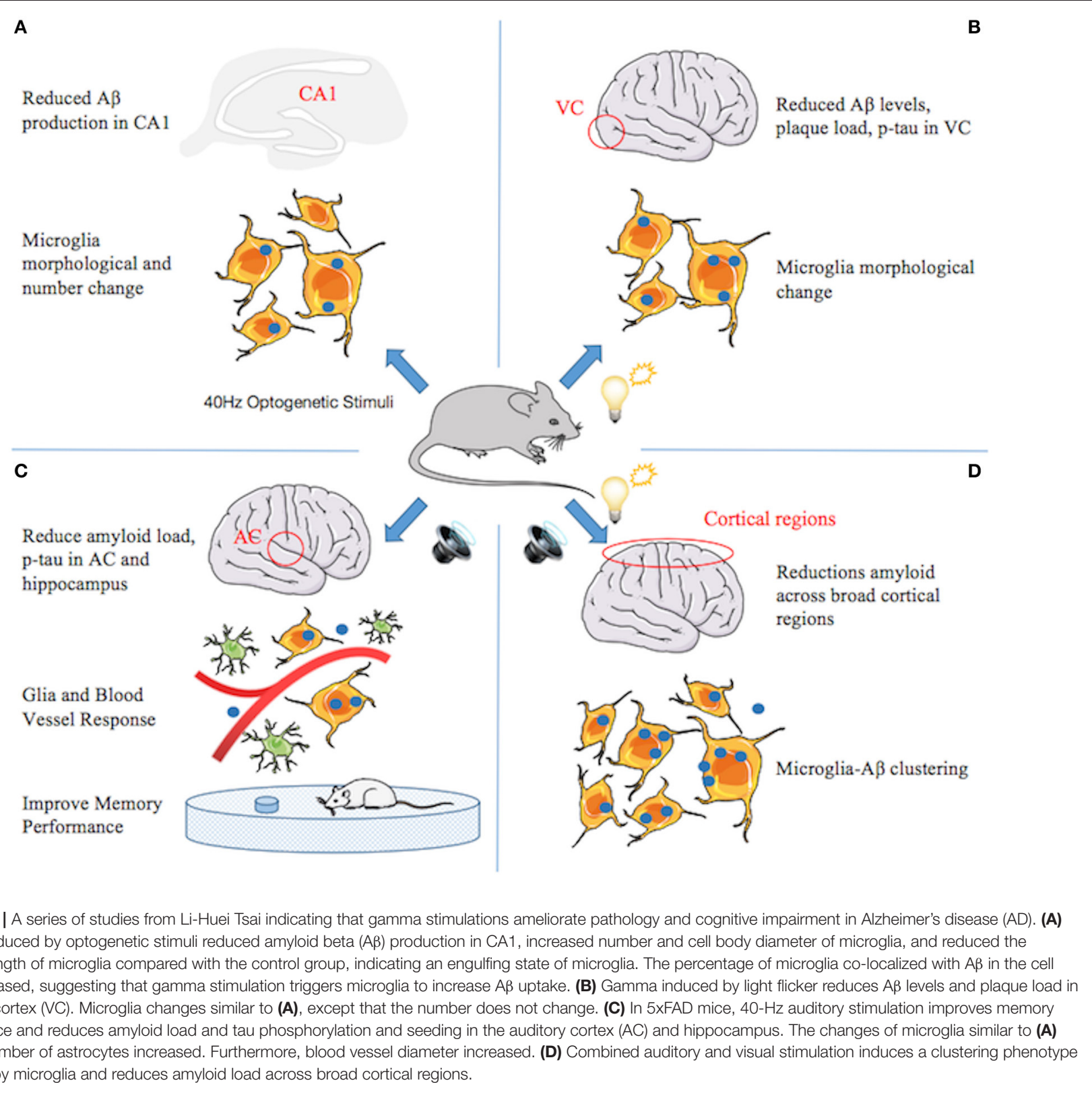

Recently, new research by Martorell suggested that auditory tone stimulation has similar effects to visual stimulation in increasing $\mathrm{A} \beta$ uptake by microglia, vascular-dilation response, and potential amyloid transvascular transport and in improving spatial and recognition memory (89) (Figure 2). More importantly, auditory stimulation combined with light-induced gamma oscillations in the hippocampal CA1 and auditory cortex regions of the brain in animal models of $\mathrm{AD}$ has unique effects: reducing the amyloid load across the cortex, suggesting the possibility of ADlike pathology across larger networks. Long-term treatment may be more effective than short-term treatment, by transforming neurons into less degraded states, improving synaptic function, enhancing neuroprotective factors, reducing DNA damage in neurons, and reducing the inflammatory response of microglia (90).

However, it is still unclear how non-invasive sensory stimuli are associated with endogenous gamma. Researchers have attempted to use a low-dose $\mathrm{GABA}_{\mathrm{A}}$ antagonist on 5XFAD mice and found that the effects of $40-\mathrm{Hz}$ flicker on $A \beta$ levels were completely abrogated, indicating that this process may involve the participation of GABAergic neurotransmission. In addition, whether the benefits can be transformed to humans is also a crucial issue. However, manipulating neural network oscillation disturbances may be a promising strategy to alleviate pathological changes and behavioral deficits associated with neurological diseases. 


\section{$A \beta$ and Tau Prions Spread Through the Brains of AD Patients}

Prion protein (PrPSc) is a special conformation of a protein encoded by the host, with self-reproduction ability, superior infectivity, tenacious viability, and the ability to remain concealed, even surviving in the normal denaturing environment of the digestive system. Prions can cause a variety of neurodegenerative diseases in humans, including CreutzfeldtJakob disease (CJD), Gerstmann-Sträussler-Scheinker syndrome (GSS), and fatal familial insomnia (FFI) in humans (91). These diseases can occur spontaneously or through genetics or infection.

Studies have shown that $\mathrm{A} \beta$ spreads through the brain via a pathogenic conformation similar to PrPSc (92). Brain-derived $\mathrm{A} \beta$ and synthetic $\mathrm{A} \beta$ from $\mathrm{AD}$ patients injected into the brain of transgenic mice showed prion-like appearances (93), which induced plaque formation and extensive deposition of $\mathrm{A} \beta$. Brain extracts from age-matched patients without AD showed minimal accumulation of $A \beta$ (94). An autopsy in a few studies also revealed that some patients had a large amount of $A \beta$ deposition in the brain after death, after receiving dura mater transplantation and cadaveric growth hormone, which may mean that $\mathrm{A} \beta$ can be transmitted interpersonally through iatrogenic methods. Prion-like $A \beta$ activity participates in the pathogenesis of $\mathrm{AD}$. The formation of prion-like $\mathrm{A} \beta$ begins in one or more brain regions and then spreads to other brain regions, reflecting cross-synaptic transmission.

Tau protein is also transmitted in the brain in a prion-like manner. Previous studies have focused solely on total insoluble tau because the abundance of NFT correlates with the extent of brain atrophy and cognitive decline in $\mathrm{AD}$ (95). A recent study found that low prion-like tau activity is associated with longer life spans: 100 postmortem brain tissue samples from patients who died of either sporadic or inherited AD showed the presence of both prion-like $A \beta$ and prion-like tau proteins (96). The activity of tau prion was inversely proportional to age, which means compared with the AD patients with the greatest longevity, patients who died at younger ages due to $\mathrm{AD}$ had lower concentrations of both prion-like $A \beta$ and prion-like tau at the time of death, although NFT increased. This decrease in tau prion-like activity is concurrent with a decrease in tau phosphorylation, suggesting that biochemical events such as phosphorylation may affect prion-like tau formation or regulate tau toxicity, although whether the reduction of prion-like tau in elderly $\mathrm{AD}$ patients is due to the conversion of prion-like tau to a more inert amyloid state, such as total insoluble tau, or due to its reduced production and clearance is still unclear. Therefore, the goal of developing a therapeutic approach of $\mathrm{AD}$ for prions remains yet to be achieved.

\section{A $\beta$ Interact With Hippocampal Ghrelin/GHSR1 $\alpha$ Signaling in AD}

GHSR $1 \alpha$, a member of the class A G protein-coupled receptor (GPCR) family (also known as ghrelin receptor), plays a special role in the hippocampus (97). In the healthy hippocampus, the ghrelin/GHSR1 $\alpha$ signal affects the learning, motivational, and hedonic components of eating (98). Moreover, GHSR1 $\alpha$ plays a role in hippocampal synaptic physiology and memory maintenance by regulating the dopamine receptor D1 (DRD1) to activate $\mathrm{Ca}^{2+} /$ calmodulin-dependent protein kinase II (CaMKII) via the non-canonical Gaq-Ca ${ }^{2+}$ signaling pathway $(97,99)$. Hippocampal lesions are one of the earliest lesions to appear in $\mathrm{AD}$ and affect cognitive function (100), which may be related to GHSR $1 \alpha$.

Emerging evidence suggests that the loss of GHSR1 $\alpha$ induces AD-like hippocampal synaptic stress and memory deficits (101) (Figure 3). However, the expression of GHSR1 $\alpha$ is increased in the hippocampus of $\mathrm{AD}$ patients, which may be a compensatory response to the toxic effects of $A \beta$. Most importantly, it is been proven that $A \beta$ combines with GHSR $1 \alpha$, preventing activation of GHSR $1 \alpha$ and GHSR1 $\alpha / D R D 1$ heterodimerization. The resultant reduced GHSR1 $\alpha / D R D 1$ interaction contributes to hippocampal synaptic injury, leading to memory damage (101).

GHSR $1 \alpha$ may be a target for AD treatment. GHSR $1 \alpha$ agonists such as MK0677 and LY444711 showed protective effects in animal and cell models $(102,103)$. However, clinical trials of MK0677 in AD patients failed to show clinical benefit. These results may reflect the insensitivity of GHSR $1 \alpha$ to activators in AD patients. Furthermore, it has been shown that the combined activation of GHSR $1 \alpha$ and DRD1 with their selective agonists MK0677 and SKF81297, respectively, rescues hippocampal synaptic function and cognition from $\mathrm{A} \beta$ toxicity in young 5XFAD mice (101). However, whether MK0677/SKF81297 is beneficial for older 5XFAD mice requires further investigation. Nonetheless, this study shows the potential protective effect of this dual agonist intervention in AD.

However, the roles of GHSR1 $\alpha$ may not be limited to the above. Its role in attenuating hippocampal pathology in 5XFAD mice by neurogenesis is not to be ignored (104). Ghrelin has been shown to attenuate hippocampal pathology in 5XFAD mice by neurogenesis. Similarly, coactivation of GHSR1 $\alpha$ and DRD1 promotes neurogenesis in the dentate gyrus of 5XFAD mice. GHSR $1 \alpha$ dysregulation also has a huge impact on hippocampal metabolic processes and calcium signaling, which is closely related to synaptic activity and hippocampal-dependent memory impairment in elderly and AD patients (105). In addition, GHSR $1 \alpha$ can affect the hypothalamic function and may indirectly drive hippocampal damage (106). In conclusion, the role of GHSR $1 \alpha$ in $\mathrm{AD}$ cannot be ignored and may provide some promising therapeutic targets.

\section{$A \beta$ Constrict Cerebral Capillaries in AD Pathology}

Cerebrovascular disease can lead to changes in the function of the brain (107). In early AD, angiogenesis damage and cerebral blood flow decrease, which are thought to be the first changes of $\mathrm{AD}$ (108). Studies have shown that capillaries contract abnormally in brains of $\mathrm{AD}$ patients and that gray blood flow can reduce by about $42 \%$. Animal studies have also found that exogenous $\mathrm{A} \beta$ can reduce cerebral blood flow in rats (109), which in turn promotes $\mathrm{A} \beta$ production (110). 


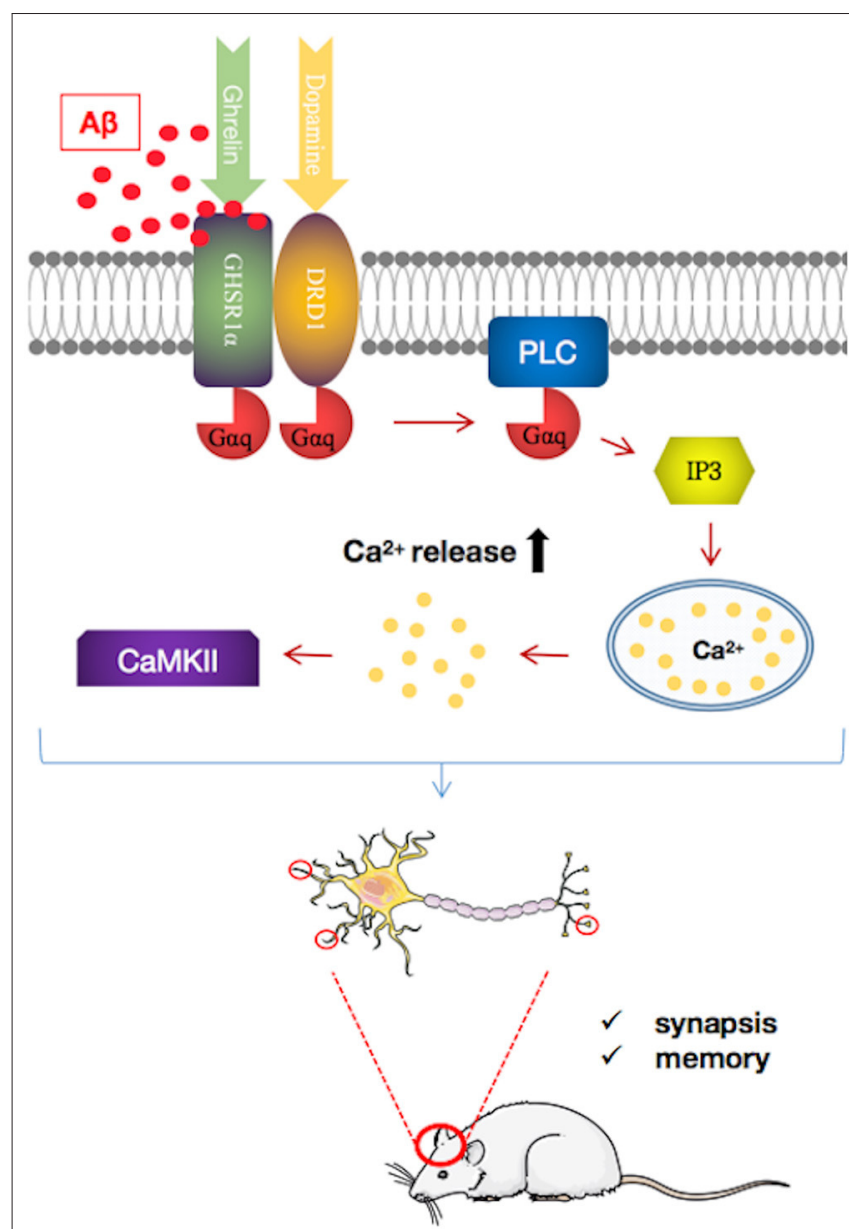

FIGURE 3 | Pathways regulating growth hormone secretagogue receptor $1 \alpha$ $(\mathrm{GHSR} 1 \alpha) /$ dopamine receptor D1 (DRD1) interaction by amyloid beta (A $\beta)$ in the hippocampus of patients with Alzheimer's disease (AD). A $\beta$ binds directly to GHSR $1 \alpha$ and inhibits the activation of GHSR $1 \alpha$ and prevented GHSR1 $\alpha / D R D 1$ heterodimerization, resulting in synaptic plasticity damage and memory loss. In a mouse model of $A D$, simultaneous use of the selective GHSR1 $\alpha$ agonist MK0677 and the selective DRD1 agonist SKF81297 rescued GHSR $1 \alpha$ function from $A \beta$ inhibition, thereby reducing hippocampal synaptic damage and improving spatial memory.

Recently, a study published in the journal Science demonstrated that in the brains of $\mathrm{AD}$ patients, $\mathrm{A} \beta$ deposition shrank the blood vessels of the brain by about $8.1 \%$ and reduced the energy supply, which resulted in a decrease of blood flow of $\sim 50 \%$, which is close to the $42 \%$ drop in blood flow in the gray matter of $\mathrm{AD}$ patients (111). $\mathrm{A} \beta$ involved the generation of reactive oxygen species (ROS), mainly by NOX4 (reduced nicotinamide adenine dinucleotide phosphate oxidase 4 ), which then triggered the release of endothelin (ET)-1, thereby acting on ETA receptors to evoke pericyte contraction (111). Pericytes became stiff and necrotic after contracting, causing capillary persistent constriction and ischemia (Figure 4). The $\mathrm{A} \beta$ oligomer played an important role in this process. Experiments conducted on human brain slices made from normal tissue showed that capillaries in brain tissues began to contract after exposure to the

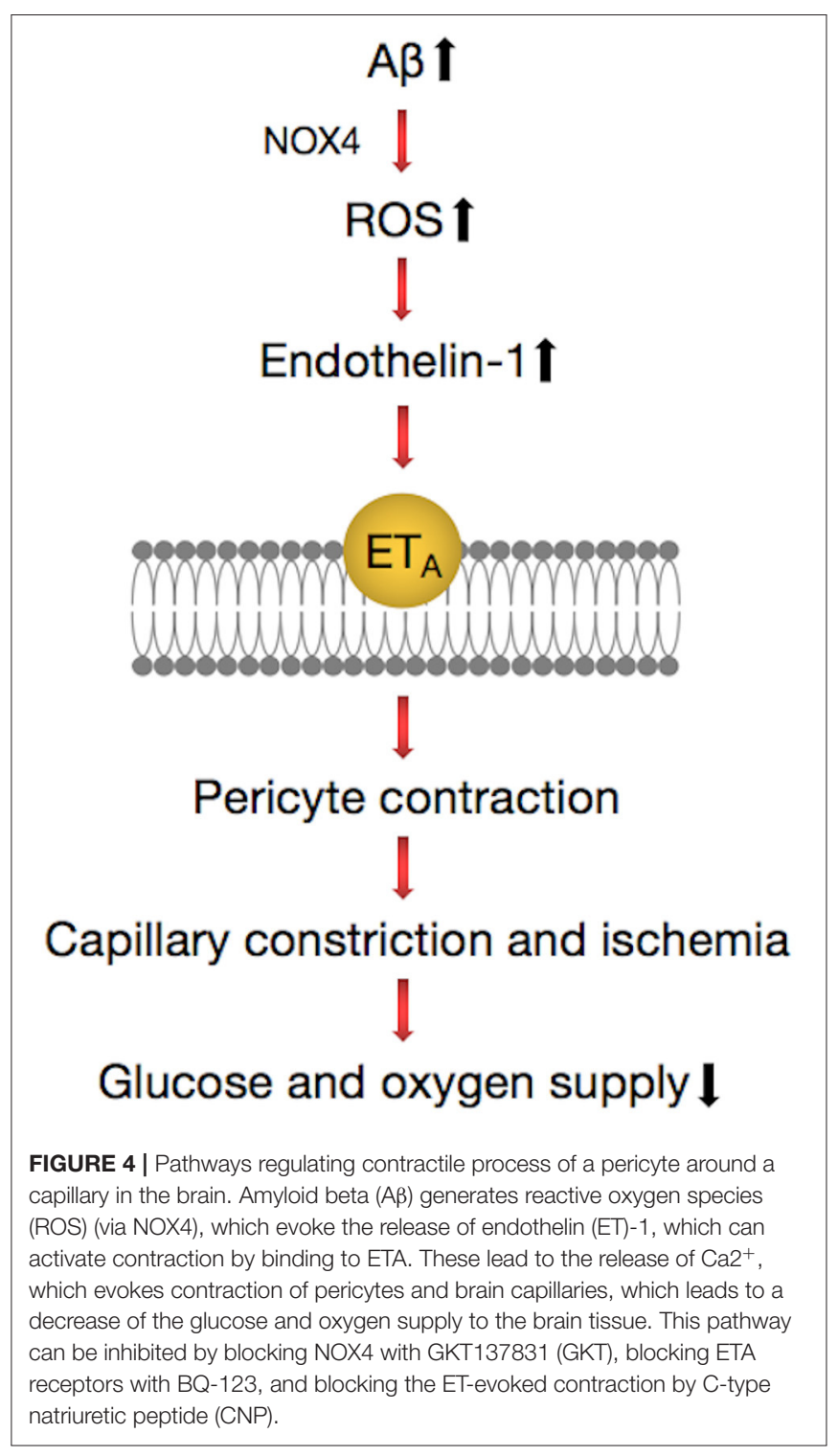

$\mathrm{A} \beta$ composition of oligomers. No similar phenomenon occurred when $\mathrm{A} \beta$ monomers were used.

The vasoconstriction mechanism described suggests that there are some potential therapies for the early treatment of $\mathrm{AD}$, such as the NOX4 inhibitor GKT137831 and the vasodilator C-type natriuretic peptide (CNP) (111), which can prevent the contraction of blood vessels. This implies that attention should be given to signaling pathways that act directly on neurons and suggest novel therapeutic approaches for early intervention in AD by targeting drugs to brain pericytes.

\section{Infection Mechanism in AD}

The brain tissue of AD patients exhibits inflammation, such as the activation of complement system factors and microglia (112). The major pathological protein of $\mathrm{AD}, \mathrm{A} \beta$, has been shown to be an antimicrobial peptide, which surrounds invaders in the brain and forms plaques to protect the brain from further 
damage. Researchers suspected that microbes are involved in the pathogenesis of $\mathrm{AD}$ since 1952 (113). Herpes virus is one of the potential pathogenic factors of $\mathrm{AD}$. HHV-6A, in particular, is involved in the host regulation of many $\mathrm{AD}$ risk genes such as $\mathrm{BACE} 1$ and $\mathrm{APBB} 2$ and promotes $\mathrm{A} \beta$ precipitation and neuronal loss by inhibiting miR-155 (114). Candida albicans, the pathogen of oral ulcers, was reported to result in a gelatinous granuloma (FIGG), similar to $\mathrm{AD}$ plaques and primary symptoms of suspected $\mathrm{AD}$, such as memory loss (115).

Porphyromonas gingivalis, the pathogen of chronic periodontitis (CP), was identified as a risk factor for dementia and $\mathrm{AD}$ and caused transient bacteremia through the mouth into the blood and then colonized in the organ (116). Gingipain, a cysteine protease consisting of lysine-gingipain (Kgp), arginine-gingipain A (RgpA), and arginine-gingipain B (RgpB), is considered a major virulence factor of $P$. gingivalis. $P$. gingivalis has been identified as an important risk factor for the development of $\mathrm{A} \beta$ plaque and $\mathrm{AD}$ (Figure 5). A prospective study supported that cognitive function in patients with active CP was significantly reduced within 6 months compared with AD patients without active CP (117). Infection with $P$. gingivalis in the oral cavity of mice leads to activation of the complement pathway in the brain (118). Porphyromonas gingivalis lipopolysaccharide has been detected in the human AD brain, suggesting its role in AD (119).

Emerging study confirmed the pathological role of $P$. gingivalis and gingipain in $\mathrm{AD}$. The gingipain immunoreactivity (IR) in AD brain was significantly higher than that in non-AD control individuals. Porphyromonas gingivalis is reported to be present in the brain and the CSF of AD patients, indicating that the DNA of $P$. gingivalis in CSF can be used as a differential diagnostic marker. Moreover, gingipain appears in the AD brain.

Oral infection with $P$. gingivalis results in brain infection of mice and induction of $A \beta 1-42$, which is toxic to host cells. Loss of biological function of $A \beta$ as an antimicrobial peptide after APP mutation may lead to further infections (120). Tau phosphorylation and tau cleavage are reported to change by direct damage or activation of procaspase-3 (which can be cleaved to activate caspase-3) by gingipain proteolysis (121). Porphyromonas gingivalis has been hypothesized to relate to human APOE (119), producing neurotoxic APOE fragments

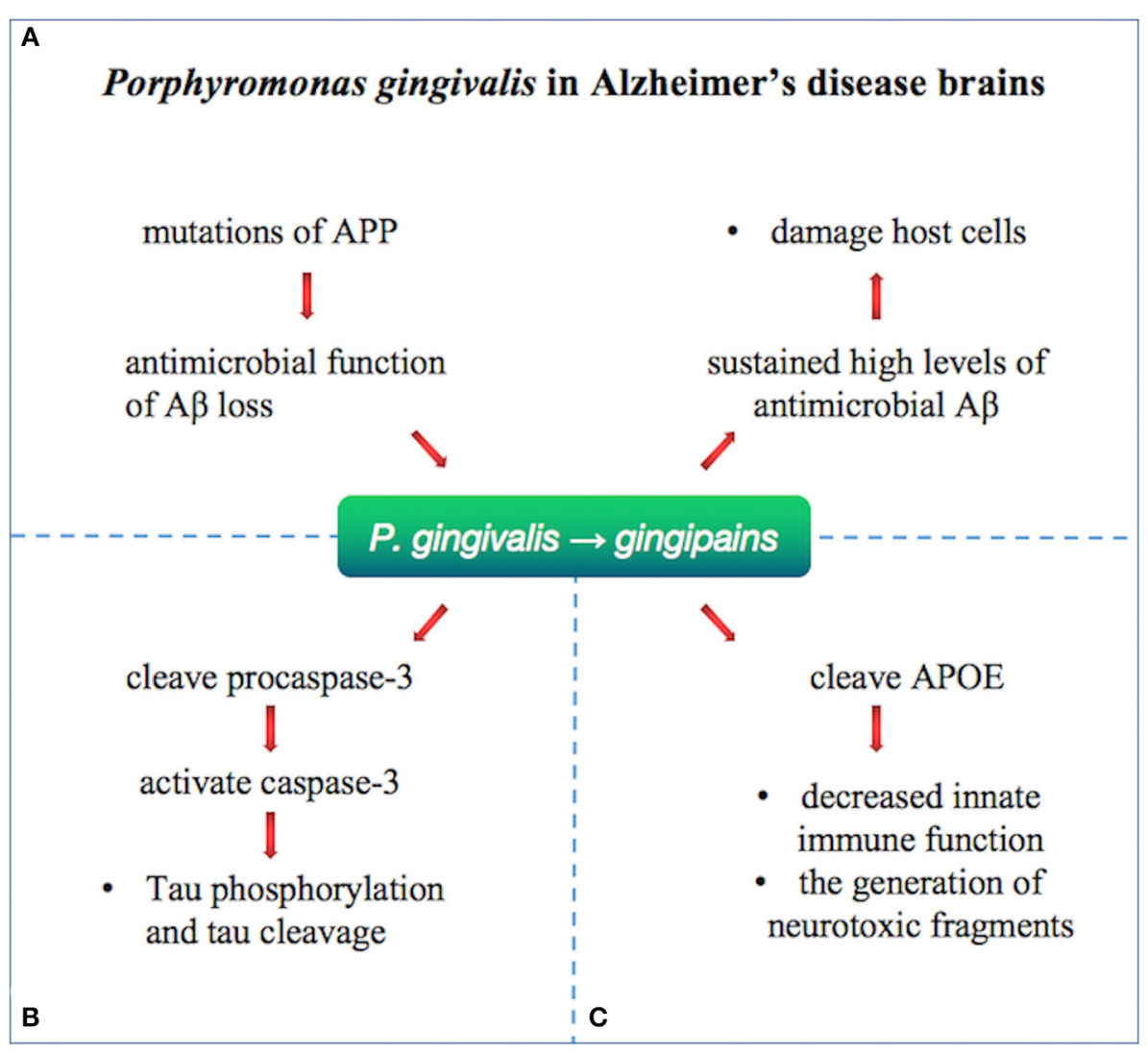

FIGURE 5 | Porphyromonas gingivalis in Alzheimer's disease brains. Porphyromonas gingivalis were identified in the brain of Alzheimer's disease patients and relate to $A \beta$, tau, and APOE by gingipains. (A) Loss of biological function of $A \beta$ as an antimicrobial peptide after APP mutation may lead to further infections. The infection with $P$. gingivalis results in brain infection of mice and induction of A1-42, which is toxic to host cells. (B) Gingipain proteolysis cause direct damage or activation of procaspase-3 (which can be cleaved to activate caspase-3), resulting in Tau phosphorylation and tau cleavage change. (C) APOE4 may be more vulnerable to gingipain cracking, producing neurotoxic APOE fragments and resulting in decreased innate immune function. 
and resulting in decreased innate immune function. Effective, selective, permeable brain small molecule gingipain inhibitors are neuroprotective (119). In vivo, it was shown that oral administration of small molecule gingipain inhibitors blocked gingipain-induced neurodegeneration and significantly reduced the load of $P$. gingivalis in mouse brain.

\section{CONCLUSION}

The $\mathrm{A} \beta$ cascade hypothesis and tau hyperphosphorylation hypothesis were formulated on the basis of strong genetic, biochemical, and histopathological evidence and were later strengthened by longitudinal biomarker, cognitive, and clinical studies. However, the corresponding clinical drug research has not identified ideal therapeutics. For example, drugs that inhibit $A \beta$ production or accelerate $A \beta$ clearance are highly anticipated. These have probably not yet been identified because whether $A \beta$ accumulation is the cause, or the result, remains unknown. In the meantime, many researchers have begun to explore the pathological mechanisms of $\mathrm{AD}$ from different

\section{REFERENCES}

1. Bondi MW, Edmonds EC, Salmon DP. Alzheimer's disease: past, present, and future. J Int Neuropsychol Soc. (2017) 23:818-31. doi: $10.1017 /$ S135561771700100X

2. Alzheimer's disease facts and figures. Alzheimers Dement. (2018) 14:367-429. doi: 10.1016/j.jalz.2018.02.001

3. Brookmeyer R, Gray S, Kawas C. Projections of Alzheimer's disease in the United States and the public health impact of delaying disease onset. Am J Public Health. (1998) 88:1337-42. doi: 10.2105/AJPH.88.9.1337

4. Tanzi RE. The genetics of Alzheimer disease. Cold Spring Harb Perspect Med. (2012) 2:a006296. doi: 10.1101/cshperspect.a006296

5. Lambert JC, Amouyel P. Genetics of Alzheimer's disease: new evidences for an old hypothesis? Curr Opin Genet Dev. (2011) 21:295-301. doi: 10.1016/j.gde.2011.02.002

6. Giri M, Zhang M, Lu Y. Genes associated with Alzheimer's disease: an overview and current status. Clin Interv Aging. (2016) 11:665-81. doi: 10.2147/CIA.S105769

7. Mahley RW. Apolipoprotein E: cholesterol transport protein with expanding role in cell biology. Science. (1988) 240:622-30. doi: 10.1126/science.3283935

8. Bales KR, Liu F, Wu S, Lin S, Koger D, DeLong C, et al. Human APOE isoform-dependent effects on brain beta-amyloid levels in PDAPP transgenic mice. J Neurosci. (2009) 29:6771-9. doi: 10.1523/JNEUROSCI.0887-0 9.2009

9. Ye S, Huang Y, Mullendorff K, Dong L, Giedt G, Meng EC, et al. Apolipoprotein. (apo) E4 enhances amyloid beta peptide production in cultured neuronal cells: apoE structure as a potential therapeutic target. Proc Natl Acad Sci USA. (2005) 102:18700-5. doi: 10.1073/pnas.0508693102

10. Brodbeck J, McGuire J, Liu Z, Meyer-Franke A, Balestra ME, Jeong DE, et al. Structure-dependent impairment of intracellular apolipoprotein E4 trafficking and its detrimental effects are rescued by small-molecule structure correctors. J Biol Chem. (2011) 286:17217-26. doi: 10.1074/jbc.M110. 217380

11. Serrano-Pozo A, Qian J, Monsell SE, Betensky RA, Hyman BT. APOEepsilon2 is associated with milder clinical and pathological Alzheimer disease. Ann Neurol. (2015) 77:917-29. doi: 10.1002/ana.24369

12. Yamagata K, Urakami K, Ikeda K, Ji Y, Adachi Y, Arai H, et al. High expression of apolipoprotein E mRNA in the brains with sporadic Alzheimer's disease. Dement Geriatr Cogn Disord. (2001) 12:57-62. doi: $10.1159 / 000051236$ perspectives. The gamma oscillations caused by auditory and visual stimulation are of note. In addition, there are $A \beta$ and tau prion transmission mechanisms, cerebral vasoconstriction, GHSR1 $\alpha$-mediated mechanisms, and infection. All of these offer new strategies for $\mathrm{AD}$ research, and based on these, prevention and earlier treatment of AD may be possible.

\section{AUTHOR CONTRIBUTIONS}

LF, CM, and $\mathrm{XH}$ conceived and wrote the manuscript. YX and CS provided funding. SZ, ZY, ZH, HS, YF, YD, and JY collected resources.

\section{FUNDING}

This work was supported by the National Natural Science Foundation of China (Grants U190420029, 91849115, and 81530037 to YX; Grants 81771290 and 81974211 to CS; and Grant 81901300 to CM) and National Key R\&D Program of China (Grant 2017YFA0105003 to YX).

13. Raygani AV, Zahrai M, Raygani AV, Doosti M, Javadi E, Rezae $\mathrm{M}$, et al. Association between apolipoprotein $\mathrm{E}$ polymorphism and Alzheimer disease in Tehran, Iran. Neurosci Lett. (2005) 375:1-6. doi: 10.1016/j.neulet.2004.10.073

14. Hudry E, Dashkoff J, Roe AD, Takeda S, Koffie RM, Hashimoto T, et al. Gene transfer of human Apoe isoforms results in differential modulation of amyloid deposition and neurotoxicity in mouse brain. Sci Transl Med. (2013) 5:212ra161. doi: 10.1126/scitranslmed. 3007000

15. Pankiewicz JE, Guridi M, Kim J, Asuni AA, Sanchez S, Sullivan $\mathrm{PM}$, et al. Blocking the apoE/A $\beta$ interaction ameliorates $\mathrm{A} \beta$-related pathology in APOE epsilon2 and epsilon4 targeted replacement Alzheimer model mice. Acta Neuropathol Commun. (2014) 2:75. doi: 10.1186/PREACCEPT-1147957959132865

16. Selkoe DJ. The molecular pathology of Alzheimer's disease. Neuron. (1991) 6:487-98. doi: 10.1016/0896-6273(91)90052-2

17. Frost B, Jacks RL, Diamond MI. Propagation of tau misfolding from the outside to the inside of a cell. J Biol Chem. (2009) 284:12845-52. doi: 10.1074/jbc.M808759200

18. Butterfield DA, Halliwell B. Oxidative stress, dysfunctional glucose metabolism and Alzheimer disease. Nat Rev Neurosci. (2019) 20:148-60. doi: 10.1038/s41583-019-0132-6

19. Glenner GG, Wong CW. Alzheimer's disease: initial report of the purification and characterization of a novel cerebrovascular amyloid protein. Biochem Biophys Res Commun. (1984) 120:885-90. doi: 10.1016/S0006-291X(84)80190-4

20. Hardy J, Allsop D. Amyloid deposition as the central event in the aetiology of Alzheimer's disease. Trends Pharmacol Sci. (1991) 12:383-8. doi: 10.1016/0165-6147(91)90609-V

21. Coronel R, Bernabeu-Zornoza A, Palmer C, Muniz-Moreno M, Zambrano A, Cano E, et al. Role of amyloid precursor protein. (APP) and its derivatives in the biology and cell fate specification of neural stem cells. Mol Neurobiol. (2018) 55:7107-17. doi: 10.1007/s12035-018-0914-2

22. Scheuner D, Eckman C, Jensen M, Song X, Citron M, Suzuki N, et al. Secreted amyloid beta-protein similar to that in the senile plaques of Alzheimer's disease is increased in vivo by the presenilin 1 and 2 and APP mutations linked to familial Alzheimer's disease. Nat Med. (1996) 2:864-70. doi: $10.1038 / \mathrm{nm} 0896-864$

23. Di Carlo M, Giacomazza D, San Biagio PL. Alzheimer's disease: biological aspects, therapeutic perspectives and diagnostic tools. J Phys Condens Matter. (2012) 24:244102. doi: 10.1088/0953-8984/24/24/244102 
24. Hardy JA, Higgins GA. Alzheimer's disease: the amyloid cascade hypothesis. Science. (1992) 256:184-5. doi: 10.1126/science. 1566067

25. Hardy J, Selkoe DJ. The amyloid hypothesis of Alzheimer's disease: progress and problems on the road to therapeutics. Science. (2002) 297:353-6. doi: $10.1126 /$ science.1072994

26. Lustbader JW, Cirilli M, Lin C, Xu HW, Takuma K, Wang N, et al. ABAD directly links Abeta to mitochondrial toxicity in Alzheimer's disease. Science. (2004) 304:448-52. doi: 10.1126/science.1091230

27. Hunt DL, Castillo PE. Synaptic plasticity of NMDA receptors: mechanisms and functional implications. Curr Opin Neurobiol. (2012) 22:496-508. doi: 10.1016/j.conb.2012.01.007

28. Vergara C, Houben S, Suain V, Yilmaz Z, De Decker R, Vanden Dries $V$, et al. Amyloid- $\beta$ pathology enhances pathological fibrillary tau seeding induced by Alzheimer PHF in vivo. Acta Neuropathol. (2019) 137:397-412. doi: 10.1007/s00401-018-1953-5

29. Rasool S, Martinez-Coria H, Wu JW, LaFerla F, Glabe CG. Systemic vaccination with anti-oligomeric monoclonal antibodies improves cognitive function by reducing $\mathrm{A} \beta$ deposition and tau pathology in $3 \times \mathrm{Tg}-\mathrm{AD}$ mice. $J$ Neurochem. (2013) 126:473-82. doi: 10.1111/jnc. 12305

30. Ferreira ST, Klein WL. The A $\beta$ oligomer hypothesis for synapse failure and memory loss in Alzheimer's disease. Neurobiol Learn Mem. (2011) 96:529-43. doi: 10.1016/j.nlm.2011.08.003

31. Holtta M, Hansson O, Andreasson U, Hertze J, Minthon L, Nagga $\mathrm{K}$, et al. Evaluating amyloid- $\beta$ oligomers in cerebrospinal fluid as a biomarker for Alzheimer's disease. PLoS ONE. (2013) 8:e66381. doi: 10.1371/journal.pone.0066381

32. Shankar GM, Li S, Mehta TH, Garcia-Munoz A, Shepardson NE, Smith I, et al. Amyloid- $\beta$ protein dimers isolated directly from Alzheimer's brains impair synaptic plasticity and memory. Nat Med. (2008) 14:837-42. doi: $10.1038 / \mathrm{nm} 1782$

33. Palop JJ, Mucke L. Network abnormalities and interneuron dysfunction in Alzheimer disease. Nat Rev Neurosci. (2016) 17:777-92. doi: 10.1038/nrn.2016.141

34. Li S, Hong S, Shepardson NE, Walsh DM, Shankar GM, Selkoe D. Soluble oligomers of amyloid Beta protein facilitate hippocampal longterm depression by disrupting neuronal glutamate uptake. Neuron. (2009) 62:788-801. doi: 10.1016/j.neuron.2009.05.012

35. Butterfield DA, Boyd-Kimball D. Oxidative stress, amyloid- $\beta$ peptide, and altered key molecular pathways in the pathogenesis and progression of alzheimer's disease. J Alzheimers Dis. (2018) 62:1345-67. doi: 10.3233/JAD-170543

36. Jolivalt CG, Hurford R, Lee CA, Dumaop W, Rockenstein E, Masliah E. Type 1 diabetes exaggerates features of Alzheimer's disease in APP transgenic mice. Exp Neurol. (2010) 223:422-31. doi: 10.1016/j.expneurol.2009.11.005

37. Karran E, Mercken M, De Strooper B. The amyloid cascade hypothesis for Alzheimer's disease: an appraisal for the development of therapeutics. Nat Rev Drug Discov. (2011) 10:698-712. doi: 10.1038/nrd3505

38. Chang WP, Koelsch G, Wong S, Downs D, Da H, Weerasena V, et al. In vivo inhibition of Abeta production by memapsin 2. (beta-secretase) inhibitors. J Neurochem. (2004) 89:1409-16. doi: 10.1111/j.1471-4159.2004. 02452.x

39. McConlogue L, Buttini M, Anderson JP, Brigham EF, Chen KS, Freedman $\mathrm{SB}$, et al. Partial reduction of BACE1 has dramatic effects on Alzheimer plaque and synaptic pathology in APP Transgenic Mice. J Biol Chem. (2007) 282:26326-34. doi: 10.1074/jbc.M611687200

40. Wong GT, Manfra D, Poulet FM, Zhang Q, Josien H, Bara T, et al. Chronic treatment with the gamma-secretase inhibitor LY-411,575 inhibits beta-amyloid peptide production and alters lymphopoiesis and intestinal cell differentiation. J Biol Chem. (2004) 279:12876-82. doi: $10.1074 /$ jbc.M311652200

41. Geling A, Steiner H, Willem M, Bally-Cuif L, Haass C. A gammasecretase inhibitor blocks Notch signaling in vivo and causes a severe neurogenic phenotype in zebrafish. EMBO Rep. (2002) 3:688-94. doi: 10.1093/embo-reports/kvf124

42. Doerfler P, Shearman MS, Perlmutter RM. Presenilin-dependent gammasecretase activity modulates thymocyte development. Proc Natl Acad Sci USA. (2001) 98:9312-7. doi: 10.1073/pnas.161102498
43. Milano J, McKay J, Dagenais C, Foster-Brown L, Pognan F, Gadient $\mathrm{R}$, et al. Modulation of notch processing by gamma-secretase inhibitors causes intestinal goblet cell metaplasia and induction of genes known to specify gut secretory lineage differentiation. Toxicol Sci. (2004) 82:341-58. doi: $10.1093 /$ toxsci/kfh 254

44. Doody RS, Raman R, Farlow M, Iwatsubo T, Vellas B, Joffe S, et al. A phase 3 trial of semagacestat for treatment of Alzheimer's disease. N Engl J Med. (2013) 369:341-50. doi: 10.1056/NEJMoa1210951

45. Schneider LS, Mangialasche F, Andreasen N, Feldman H, Giacobini E, Jones $\mathrm{R}$, et al. Clinical trials and late-stage drug development for Alzheimer's disease: an appraisal from 1984 to 2014. J Intern Med. (2014) 275:251-83. doi: 10.1111/joim.12191

46. Hemming ML, Elias JE, Gygi SP, Selkoe DJ. Identification of beta-secretase. (BACE1) substrates using quantitative proteomics. PLoS ONE. (2009) 4:e8477. doi: 10.1371/journal.pone.0008477

47. Egan MF, Kost J, Tariot PN, Aisen PS, Cummings JL, Vellas B, et al. Randomized trial of verubecestat for mild-to-moderate alzheimer's disease. N Engl J Med. (2018) 378:1691-703. doi: 10.1056/NEJMoa1706441

48. Hawkes N. Merck ends trial of potential Alzheimer's drug verubecestat. $B M J$. (2017) 356:j845. doi: 10.1136/bmj.j845

49. Burgos-Ramos E, Hervas-Aguilar A, Aguado-Llera D, Puebla-Jimenez L, Hernandez-Pinto AM, Barrios V, et al. Somatostatin and Alzheimer's disease. Mol Cell Endocrinol. (2008) 286:104-11. doi: 10.1016/j.mce.2008.01.014

50. Zlokovic BV, Deane R, Sagare AP, Bell RD, Winkler EA. Lowdensity lipoprotein receptor-related protein-1: a serial clearance homeostatic mechanism controlling Alzheimer's amyloid $\beta$-peptide elimination from the brain. I Neurochem. (2010) 115:1077-89. doi: 10.1111/j.1471-4159.2010.07002.x

51. Hawkes CA, Deng LH, Shaw JE, Nitz M, McLaurin J. Small molecule betaamyloid inhibitors that stabilize protofibrillar structures in vitro improve cognition and pathology in a mouse model of Alzheimer's disease. Eur J Neurosci. (2010) 31:203-13. doi: 10.1111/j.1460-9568.2009.07052.x

52. Burstein AH, Sabbagh M, Andrews R, Valcarce C, Dunn I, Altstiel L. Development of azeliragon, an oral small molecule antagonist of the receptor for advanced glycation endproducts, for the potential slowing of loss of cognition in mild alzheimer's disease. J Prev Alzheimers Dis. (2018) 5:149-54. doi: 10.14283/jpad.2018.18

53. Shea D, Hsu CC, Bi TM, Paranjapye N, Childers MC, Cochran J, et al. $\alpha$-Sheet secondary structure in amyloid $\beta$-peptide drives aggregation and toxicity in Alzheimer's disease. Proc Natl Acad Sci USA. (2019) 116:8895-900. doi: 10.1073/pnas. 1820585116

54. Neve RL, Harris P, Kosik KS, Kurnit DM, Donlon TA. Identification of cDNA clones for the human microtubule-associated protein tau and chromosomal localization of the genes for tau and microtubule-associated protein 2. Brain Res. (1986) 387:271-80. doi: 10.1016/0169-328X(86)90033-1

55. Wischik CM, Novak M, Edwards PC, Klug A, Tichelaar W, Crowther RA. Structural characterization of the core of the paired helical filament of Alzheimer disease. Proc Natl Acad Sci USA. (1988) 85:4884-8. doi: $10.1073 /$ pnas.85.13.4884

56. Regan P, Whitcomb DJ, Cho K. Physiological and pathophysiological implications of synaptic tau. Neuroscientist. (2017) 23:137-51. doi: $10.1177 / 1073858416633439$

57. Jean DC, Baas PW. It cuts two ways: microtubule loss during Alzheimer disease. Embo J. (2013) 32:2900-2. doi: 10.1038/emboj.2013.219

58. Dixit R, Ross JL, Goldman YE, Holzbaur EL. Differential regulation of dynein and kinesin motor proteins by tau. Science. (2008) 319:1086-9. doi: $10.1126 /$ science. 1152993

59. Kimura T, Whitcomb DJ, Jo J, Regan P, Piers T, Heo S, et al. Microtubuleassociated protein tau is essential for long-term depression in the hippocampus. Philos Trans R Soc Lond B Biol Sci. (2014) 369:20130144. doi: 10.1098/rstb.2013.0144

60. Grundke-Iqbal I, Iqbal K, Tung YC, Quinlan M, Wisniewski HM, Binder LI. Abnormal phosphorylation of the microtubule-associated protein tau. (tau) in Alzheimer cytoskeletal pathology. Proc Natl Acad Sci USA. (1986) 83:4913-7. doi: 10.1073/pnas.83.13.4913

61. Dickey CA, Kamal A, Lundgren K, Klosak N, Bailey RM, Dunmore J, et al. The high-affinity HSP90-CHIP complex recognizes and selectively 
degrades phosphorylated tau client proteins. J Clin Invest. (2007) 117:648-58. doi: 10.1172/JCI29715

62. Jara C, Aranguiz A, Cerpa W, Tapia-Rojas C, Quintanilla RA. Genetic ablation of tau improves mitochondrial function and cognitive abilities in the hippocampus. Redox Biol. (2018) 18:279-94. doi: 10.1016/j.redox.2018.07.010

63. Khan SS, Bloom GS. Tau: The Center of a Signaling Nexus in Alzheimer's Disease. Front Neurosci. (2016) 10:31. doi: 10.3389/fnins.2016.00031

64. Callahan LM, Vaules WA, Coleman PD. Quantitative decrease in synaptophysin message expression and increase in cathepsin D message expression in Alzheimer disease neurons containing neurofibrillary tangles. J Neuropathol Exp Neurol. (1999) 58:275-87. doi: 10.1097/00005072-199903000-00007

65. Mocanu MM, Nissen A, Eckermann K, Khlistunova I, Biernat J, Drexler D, et al. The potential for beta-structure in the repeat domain of tau protein determines aggregation, synaptic decay, neuronal loss, and coassembly with endogenous Tau in inducible mouse models of tauopathy. J Neurosci. (2008) 28:737-48. doi: 10.1523/JNEUROSCI.2824-07.2008

66. Busche MA, Wegmann S, Dujardin S, Commins C, Schiantarelli J, Klickstein $\mathrm{N}$, et al. Tau impairs neural circuits, dominating amyloid$\beta$ effects, in Alzheimer models in vivo. Nat Neurosci. (2019) 22:57-64. doi: 10.1038/s41593-018-0289-8

67. Cotman CW, Poon WW, Rissman RA, Blurton-Jones M. The role of caspase cleavage of tau in Alzheimer disease neuropathology. J Neuropathol Exp Neurol. (2005) 64:104-12. doi: 10.1093/jnen/64.2.104

68. Guo T, Noble W, Hanger DP. Roles of tau protein in health and disease. Acta Neuropathol. (2017) 133:665-704. doi: 10.1007/s00401-017-1707-9

69. Jadhav S, Katina S, Kovac A, Kazmerova Z, Novak M, Zilka N. Truncated tau deregulates synaptic markers in rat model for human tauopathy. Front Cell Neurosci. (2015) 9:24. doi: 10.3389/fncel.2015.00024

70. Takeda S, Wegmann S, Cho H, DeVos SL, Commins C, Roe AD, et al. Neuronal uptake and propagation of a rare phosphorylated high-molecularweight tau derived from Alzheimer's disease brain. Nat Commun. (2015) 6:8490. doi: $10.1038 /$ ncomms 9490

71. Shafiei SS, Guerrero-Munoz MJ, Castillo-Carranza DL. Tau oligomers: cytotoxicity, propagation, and mitochondrial damage. Front Aging Neurosci. (2017) 9:83. doi: 10.3389/fnagi.2017.00083

72. Gauthier S, Feldman HH, Schneider LS, Wilcock GK, Frisoni GB, Hardlund $\mathrm{JH}$, et al. Efficacy and safety of tau-aggregation inhibitor therapy in patients with mild or moderate Alzheimer's disease: a randomised, controlled, double-blind, parallel-arm, phase 3 trial. Lancet. (2016) 388:2873-84. doi: 10.1016/S0140-6736(16)31275-2

73. Bollag DM, McQueney PA, Zhu J, Hensens O, Koupal L, Liesch J, et al. Epothilones, a new class of microtubule-stabilizing agents with a taxol-like mechanism of action. Cancer Res. (1995) 55:2325-33.

74. Barten DM, Fanara P, Andorfer C, Hoque N, Wong PY, Husted $\mathrm{KH}$, et al. Hyperdynamic microtubules, cognitive deficits, and pathology are improved in tau transgenic mice with low doses of the microtubule-stabilizing agent BMS-241027. J Neurosci. (2012) 32:7137-45. doi: 10.1523/JNEUROSCI.0188-12.2012

75. McGeer PL, Rogers J. Anti-inflammatory agents as a therapeutic approach to Alzheimer's disease. Neurology. (1992) 42:447-9. doi: 10.1212/WNL.42.2.447

76. Panza F, Lozupone M, Logroscino G, Imbimbo BP. A critical appraisal of amyloid- $\beta$-targeting therapies for Alzheimer disease. Nat Rev Neurol. (2019) 15:73-88. doi: 10.1038/s41582-018-0116-6

77. Graham WV, Bonito-Oliva A, Sakmar TP. Update on alzheimer's disease therapy and prevention strategies. Annu Rev Med. (2017) 68:413-30. doi: 10.1146/annurev-med-042915-103753

78. Aoyagi A, Condello C, Stohr J, Yue W, Rivera BM, Lee JC, et al. A $\beta$ and tau prion-like activities decline with longevity in the Alzheimer's disease human brain. Sci Transl Med. (2019) 11:eaat8462. doi: 10.1126/scitranslmed.aat8462

79. Boada-Rovira M, Brodaty H, Cras P, Baloyannis S, Emre M, Zhang R, et al. Efficacy and safety of donepezil in patients with Alzheimer's disease: results of a global, multinational, clinical experience study. Drugs Aging. (2004) 21:43-53. doi: 10.2165/00002512-200421010-00004

80. Egan MF, Kost J, Voss T, Mukai Y, Aisen PS, Cummings JL, et al. Randomized trial of verubecestat for prodromal alzheimer's disease. N Engl J Med. (2019) 380:1408-20. doi: 10.1056/NEJMoa1812840
81. Kishi T, Matsunaga S, Oya K, Nomura I, Ikuta T, Iwata N. Memantine for alzheimer's disease: an updated systematic review and meta-analysis. $J$ Alzheimers Dis. (2017) 60:401-25. doi: 10.3233/JAD-170424

82. Gallini A, Sommet A, Montastruc JL. Does memantine induce bradycardia? a study in the french pharmacovigilance database. Pharmacoepidemiol Drug Saf. (2008) 17:877-81. doi: 10.1002/pds.1620

83. Cummings JL, Morstorf T, Zhong K. Alzheimer's disease drug-development pipeline: few candidates, frequent failures. Alzheimers Res Ther. (2014) 6:37. doi: $10.1186 /$ alzrt269

84. Colgin LL, Moser EI. Gamma oscillations in the hippocampus. Physiology. (2010) 25:319-29. doi: 10.1152/physiol.00021.2010

85. Goutagny R, Gu N, Cavanagh C, Jackson J, Chabot JG, Quirion R, et al. Alterations in hippocampal network oscillations and theta-gamma coupling arise before $\mathrm{A} \beta$ overproduction in a mouse model of Alzheimer's disease. Eur J Neurosci. (2013) 37:1896-902. doi: 10.1111/ejn.12233

86. Mably AJ, Gereke BJ, Jones DT, Colgin LL. Impairments in spatial representations and rhythmic coordination of place cells in the $3 \times \mathrm{Tg}$ mouse model of Alzheimer's disease. Hippocampus. (2017) 27:378-92. doi: 10.1002/hipo.22697

87. Booth CA, Witton J, Nowacki J, Tsaneva-Atanasova K, Jones MW, Randall $\mathrm{AD}$, et al. Altered intrinsic pyramidal neuron properties and pathwayspecific synaptic dysfunction underlie aberrant hippocampal network function in a mouse model of tauopathy. $J$ Neurosci. (2016) 36:350-63. doi: 10.1523/JNEUROSCI.2151-15.2016

88. Gillespie AK, Jones EA, Lin YH, Karlsson MP, Kay K, Yoon SY, et al. Apolipoprotein E4 causes age-dependent disruption of slow gamma oscillations during hippocampal sharp-wave ripples. Neuron. (2016) 90:74051. doi: 10.1016/j.neuron.2016.04.009

89. Iaccarino HF, Singer AC, Martorell AJ, Rudenko A, Gao F, Gillingham $\mathrm{TZ}$, et al. Gamma frequency entrainment attenuates amyloid load and modifies microglia. Nature. (2016) 540:230-5. doi: 10.1038/nature 20587

90. Martorell AJ, Paulson AL, Suk HJ, Abdurrob F, Drummond GT, Guan $\mathrm{W}$, et al. Multi-sensory gamma stimulation ameliorates alzheimer'sassociated pathology and improves cognition. Cell. (2019) 177:256-71.e22. doi: 10.1016/j.cell.2019.02.014

91. Adaikkan C, Middleton SJ, Marco A, Pao PC, Mathys H, Kim DN, et al. Gamma entrainment binds higher-order brain regions and offers neuroprotection. Neuron. (2019) 102:929-43.e8. doi: 10.1016/j.neuron.2019.04.011

92. Prusiner SB. Cell biology. A unifying role for prions in neurodegenerative diseases. Science. (2012) 336:1511-3. doi: 10.1126/science.1222951

93. Condello $\mathrm{C}$, Stoehr J. A $\beta$ propagation and strains: Implications for the phenotypic diversity in Alzheimer's disease. Neurobiol Dis. (2018) 109(Pt B):191-200. doi: 10.1016/j.nbd.2017.03.014

94. Woerman AL, Patel S, Kazmi SA, Oehler A, Freyman Y, Espiritu $\mathrm{L}$, et al. Kinetics of human mutant tau prion formation in the brains of 2 transgenic mouse lines. JAMA Neurol. (2017) 74:1464-72. doi: 10.1001/jamaneurol.2017.2822

95. Stohr J, Condello C, Watts JC, Bloch L, Oehler A, Nick M, et al. Distinct synthetic A $\beta$ prion strains producing different amyloid deposits in bigenic mice. Proc Natl Acad Sci USA. (2014) 111:10329-34. doi: 10.1073/pnas.1408968111

96. Jack CR, Jr, Knopman DS, Jagust WJ, Petersen RC, Weiner MW, Aisen PS, et al. Tracking pathophysiological processes in Alzheimer's disease: an updated hypothetical model of dynamic biomarkers. Lancet Neurol. (2013) 12:207-16. doi: 10.1016/S1474-4422(12)70291-0

97. Kern A, Mavrikaki M, Ullrich C, Albarran-Zeckler R, Brantley AF, Smith RG. Hippocampal dopamine/DRD1 signaling dependent on the ghrelin receptor. Cell. (2015) 163:1176-90. doi: 10.1016/j.cell.2015.10.062

98. Hsu TM, Noble EE, Reiner DJ, Liu CM, Suarez AN, Konanur VR, et al. Hippocampus ghrelin receptor signaling promotes socially-mediated learned food preference. Neuropharmacology. (2018) 131:487-96. doi: 10.1016/j.neuropharm.2017.11.039

99. Seminara RS, Jeet C, Biswas S, Kanwal B, Iftikhar W, Sakibuzzaman M, et al. The neurocognitive effects of ghrelin-induced signaling on the hippocampus: a promising approach to alzheimer's disease. Cureus. (2018) 10:e3285. doi: $10.7759 /$ cureus. 3285 
100. Scheff SW, Price DA, Schmitt FA, Mufson EJ. Hippocampal synaptic loss in early Alzheimer's disease and mild cognitive impairment. Neurobiol Aging. (2006) 27:1372-84. doi: 10.1016/j.neurobiolaging.2005.09.012

101. Tian J, Guo L, Sui S, Driskill C, Phensy A, Wang Q, et al. Disrupted hippocampal growth hormone secretagogue receptor $1 \alpha$ interaction with dopamine receptor D1 plays a role in Alzheimer's disease. Sci Transl Med. (2019) 11:eaav6278. doi: 10.1126/scitranslmed.aav6278

102. Jeong YO, Shin SJ, Park JY, Ku BK, Song JS, Kim JJ, et al. MK-0677, a Ghrelin agonist, alleviates amyloid beta-related pathology in 5XFAD mice, an animal model of alzheimer's disease. Int J Mol Sci. (2018) 19:1800. doi: 10.3390/ijms19061800

103. Eslami M, Sadeghi B, Goshadrou F. Chronic ghrelin administration restores hippocampal long-term potentiation and ameliorates memory impairment in rat model of Alzheimer's disease. Hippocampus. (2018) 28:724-34. doi: 10.1002/hipo.23002

104. Moon M, Cha MY, Mook-Jung I. Impaired hippocampal neurogenesis and its enhancement with ghrelin in 5XFAD mice. J Alzheimers Dis. (2014) 41:233-41. doi: 10.3233/JAD-132417

105. Diano S, Farr SA, Benoit SC, McNay EC, da Silva I, Horvath B, et al. Ghrelin controls hippocampal spine synapse density and memory performance. Nat Neurosci. (2006) 9:381-8. doi: 10.1038/nn1656

106. Yin Y, Li Y, Zhang W. The growth hormone secretagogue receptor: its intracellular signaling and regulation. Int J Mol Sci. (2014) 15:4837-55. doi: 10.3390/ijms15034837

107. Zhu XH, Qiao H, Du F, Xiong Q, Liu X, Zhang X, et al. Quantitative imaging of energy expenditure in human brain. Neuroimage. (2012) 60:2107-17. doi: 10.1016/j.neuroimage.2012.02.013

108. Asllani I, Habeck C, Scarmeas N, Borogovac A, Brown TR, Stern Y. Multivariate and univariate analysis of continuous arterial spin labeling perfusion MRI in Alzheimer's disease. J Cereb Blood Flow Metab. (2008) 28:725-36. doi: $10.1038 /$ sj.jcbfm. 9600570

109. Suo Z, Humphrey J, Kundtz A, Sethi F, Placzek A, Crawford F, et al. Soluble Alzheimers beta-amyloid constricts the cerebral vasculature in vivo. Neurosci Lett. (1998) 257:77-80. doi: 10.1016/S0304-3940(98)00814-3

110. Sun X, He G, Qing H, Zhou W, Dobie F, Cai F, et al. Hypoxia facilitates Alzheimer's disease pathogenesis by up-regulating BACE1 gene expression. Proc Natl Acad Sci USA. (2006) 103:18727-32. doi: 10.1073/pnas.06062 98103

111. Nortley R, Korte N, Izquierdo P, Hirunpattarasilp C, Mishra A, Jaunmuktane $Z$, et al. Amyloid $\beta$ oligomers constrict human capillaries in Alzheimer's disease via signaling to pericytes. Science. (2019) 365:eaav9518. doi: 10.1126/science.aav9518

112. Kaushal V, Dye R, Pakavathkumar P, Foveau B, Flores J, Hyman $B$, et al. Neuronal NLRP1 inflammasome activation of Caspase-1 coordinately regulates inflammatory interleukin-1-beta production and axonal degeneration-associated Caspase-6 activation. Cell Death Differ. (2015) 22:1676-86. doi: 10.1038/cdd.2015.16
113. Sjogren T, Sjogren H, Lindgren AG. Morbus Alzheimer and morbus Pick; a genetic, clinical and patho-anatomical study. Acta Psychiatr Neurol Scand Suppl. (1952) 82:1-152.

114. Eimer WA, Vijaya Kumar DK, Navalpur Shanmugam NK, Rodriguez AS, Mitchell T, Washicosky KJ, et al. Alzheimer's disease-associated $\beta$-amyloid is rapidly seeded by herpesviridae to protect against brain infection. Neuron. (2018) 99:56-63.e3. doi: 10.1016/j.neuron.2018.06.030

115. Wu Y, Du S, Johnson JL, Tung HY, Landers CT, Liu Y, et al. Microglia and amyloid precursor protein coordinate control of transient Candida cerebritis with memory deficits. Nat Commun. (2019) 10:58. doi: 10.1038/s41467-018-07991-4

116. Kamer AR, Pirraglia E, Tsui W, Rusinek H, Vallabhajosula S, Mosconi L, et al. Periodontal disease associates with higher brain amyloid load in normal elderly. Neurobiol Aging. (2015) 36:627-33. doi: 10.1016/j.neurobiolaging.2014.10.038

117. Ide M, Harris M, Stevens A, Sussams R, Hopkins V, Culliford D, et al. Periodontitis and cognitive decline in alzheimer's disease. PLoS ONE. (2016) 11:e0151081. doi: 10.1371/journal.pone.0151081

118. Poole S, Singhrao SK, Chukkapalli S, Rivera M, Velsko I, Kesavalu L, et al. Active invasion of Porphyromonas gingivalis and infection-induced complement activation in $\mathrm{ApoE}^{-/-}$mice brains. J Alzheimers Dis. (2015) 43:67-80. doi: 10.3233/JAD-140315

119. Dominy SS, Lynch C, Ermini F, Benedyk M, Marczyk A, Konradi A, et al. Porphyromonas gingivalis in Alzheimer's disease brains: evidence for disease causation and treatment with small-molecule inhibitors. Sci Adv. (2019) 5:eaau3333. doi: 10.1126/sciadv.aau3333

120. Zhou R, Yang G, Shi Y. Dominant negative effect of the loss-offunction gamma-secretase mutants on the wild-type enzyme through heterooligomerization. Proc Natl Acad Sci USA. (2017) 114:12731-6. doi: 10.1073/pnas.1713605114

121. Urnowey S, Ansai T, Bitko V, Nakayama K, Takehara T, Barik S. Temporal activation of anti- and pro-apoptotic factors in human gingival fibroblasts infected with the periodontal pathogen, Porphyromonas gingivalis: potential role of bacterial proteases in host signalling. BMC Microbiol. (2006) 6:26. doi: $10.1186 / 1471-2180-6-26$

Conflict of Interest: The authors declare that the research was conducted in the absence of any commercial or financial relationships that could be construed as a potential conflict of interest.

Copyright @ 2020 Fan, Mao, Hu, Zhang, Yang, Hu, Sun, Fan, Dong, Yang, Shi and $X u$. This is an open-access article distributed under the terms of the Creative Commons Attribution License (CC BY). The use, distribution or reproduction in other forums is permitted, provided the original author(s) and the copyright owner(s) are credited and that the original publication in this journal is cited, in accordance with accepted academic practice. No use, distribution or reproduction is permitted which does not comply with these terms. 